University of Nebraska - Lincoln

DigitalCommons@University of Nebraska - Lincoln

Virology Papers

Virology, Nebraska Center for

2005

\title{
Proteomic Fingerprints Distinguish Microglia, Bone Marrow, and Spleen Macrophage Populations
}

\author{
Yoshimi Enose \\ University of Nebraska Medical Center \\ Christopher J. Destache \\ Creighton University, cjd42123@creighton.edu \\ Andrea L. Mack \\ University of Nebraska Medical Center \\ James R. Anderson \\ University of Nebraska Medical Center \\ Fred Ullrich \\ University of Nebraska Medical Center \\ See next page for additional authors
}

Follow this and additional works at: https://digitalcommons.unl.edu/virologypub

Part of the Virology Commons

Enose, Yoshimi; Destache, Christopher J.; Mack, Andrea L.; Anderson, James R.; Ullrich, Fred; Ciborowski, Pawel; and Gendelman, Howard E., "Proteomic Fingerprints Distinguish Microglia, Bone Marrow, and Spleen Macrophage Populations" (2005). Virology Papers. 194.

https://digitalcommons.unl.edu/virologypub/194

This Article is brought to you for free and open access by the Virology, Nebraska Center for at DigitalCommons@University of Nebraska - Lincoln. It has been accepted for inclusion in Virology Papers by an authorized administrator of DigitalCommons@University of Nebraska - Lincoln. 


\section{Authors}

Yoshimi Enose, Christopher J. Destache, Andrea L. Mack, James R. Anderson, Fred Ullrich, Pawel Ciborowski, and Howard E. Gendelman 
Published in Glia 51:3 (2005), pp. 161-172; doi: 10.1002/glia.20193 Copyright @ 2005 Wiley-Liss, Inc., A Wiley Company. Used by permission. http://www.interscience.wiley.com/jpages/0894-1491/

Research reported in this article was funded by National Institutes of Health; Grant Number: 2R37 NS36126, P01 NS31492, P01 NS43985, U54 NS43011-01, 2 R01 NS034239, P20 RR15635

Submitted June 24, 2004; accepted January 24, 2005; published online March 28, 2005.

\title{
Proteomic fingerprints distinguish microglia, bone marrow, and spleen macrophage populations
}

\author{
Yoshimi Enose, ${ }^{1,2}$ Christopher J. Destache, ${ }^{6}$ Andrea L. Mack,1,2 James R. Anderson, ${ }^{5}$ \\ Fred Ullrich, ${ }^{5}$ Pawel S. Ciborowski, ${ }^{1,4}$ Howard E. Gendelman ${ }^{1,2,3}$ \\ ${ }^{1}$ Center for Neurovirology and Neurodegenerative Disorders, University of Nebraska Medical Center, Omaha, Nebraska \\ ${ }^{2}$ Department of Pharmacology, University of Nebraska Medical Center, Omaha, Nebraska \\ ${ }^{3}$ Department of Internal Medicine, University of Nebraska Medical Center, Omaha, Nebraska \\ ${ }^{4}$ Department of Biochemistry and Molecular Biology, University of Nebraska Medical Center, Omaha, Nebraska \\ ${ }^{5}$ Department of Preventative and Societal Medicine, University of Nebraska Medical Center, Omaha, Nebraska \\ ${ }^{6}$ Creighton University School of Pharmacy and Health Professions, Omaha, Nebraska \\ Corresponding author - Howard E. Gendelman, Center for Neurovirology and Neurodegenerative Disorders, 985880 Nebraska Medical Center, \\ Omaha, Nebraska 68198-5880; email hegendel@unmc.edu
}

\begin{abstract}
Mononuclear phagocytes (MP; dendritic cells, monocytes, tissue macrophages, and microglia) maintain tissue homeostasis and provide a first line of defense against invading pathogens. In specific circumstances, MPs also induce inflammatory responses and as such affect disease onset and progression. Despite intensive research into MP biology, little is known of the functional and molecular properties of individual MP subtypes. Using a novel proteomics platform, unique protein patterns and protein identities were observed among populations of spleen and bone marrow macrophages and microglia. Cells were obtained from C57BL/6 mice and were cultivated in macrophage colonystimulating factor. MP subtypes were indistinguishable by morphological or antigenic criteria. Protein profiling by Surface Enhanced Laser Desorption Ionization-Time of Flight (SELDI-TOF) ProteinChip ${ }^{\circledR}$ assays with weak cationic exchange chips showed unique MP spectral profiles. Corresponding protein fractions were recovered by high performance liquid chromatography and identified by liquid chromatography tandem mass spectrometry. The results provide a unique means to distinguish microglia from other MP subtypes.
\end{abstract}

Keywords: cellular proteins, proteomics, microglia, macrophages

\section{Introduction}

Host immunity against microbial pathogens comprises defense at the portal of entry (the skin and mucosa) together with innate and adaptive immune responses. The innate immune system maintains tissue homeostasis and provides a first-line cellular defense against microbial infections. The process is regulated, in significant measure, by mononuclear phagocytes (MP; dendritic cells, monocytes, tissue macrophages, and microglia). MPs play pivotal roles in antigen capture and presentation, pathogen and tissue debris clearance, cellular secretory functions. MP populations originate in bone marrow from promonocytes (van Furth et al., 1982; van Furth, 1992) and are widely distributed throughout the body from monocyte pools including, but not limited to, lymphoid tissue, liver, lung, gastrointestinal tract, and the nervous system. Despite their common origin, macrophages are heterogeneous populations based on the residing tissues (Gordon et al., 1988; Morris et al., 1991; Laskin et al., 2001). Whether this translates into functional (Gordon et al., 1988) and antigenic differences (Taylor et al., 2003; Guillemin and Brew, 2004) is not completely understood. MP heterogeneity may be simply a consequence of cell exposure to the tissue microenvironment including local growth factors (Naito et al., 1996). The latter would include, but not be limited to, macrophage and granulocyte-macrophage colony-stimulating factors (M-CSF and GM-CSF), that affect MP differentiation, proliferation and activation (Kaplan et al., 1992; Cecchini et al., 1994; de Villiers et al., 1994, 1998; Hamilton, 1997).

The properties of MPs are studied following cell isolation and cultivation under defined laboratory conditions. This permits investigations of cell function and molecular profiles independent of the tissue microenvironment. In order to address the role that genetics and environment play in MP heterogeneity, we isolated bone marrow (BM) and spleen (SPL) macrophages and brain microglia (MG) under the same culture medium and tested whether the cells display unique protein signatures. A unique proteomic pattern of MPs was shown by Surface Enhanced Laser Desorption Ionization-Time of Flight (SELDI-TOF) ProteinChip ${ }^{\circledR}$ profiles and substantiated high-performance liquid chromatography (HPLC) fractionation and liquid chromatography tandem mass spectrometry (LC-MS/MS) protein identification. The results provide specific protein signatures for MP supporting the concept that both the tissue microenvironment and genetic composition affect cellular heterogeneity. 


\section{Materials and Methods}

\section{Cell Cultures}

$\mathrm{BM}$ and SPL macrophages and MG were prepared from C57BL/6 (male, 8-12 weeks old), and neonatal mice (1-2 days old), respectively (Charles River Laboratory, Wilmington, MA). To obtain BM-macrophages, both femurs were removed and placed in Hanks' balanced salt solution (HBSS) at $4^{\circ} \mathrm{C}$. A 5-ml syringe with a 26-gauge needle was inserted into the BM cavity and flushed with HBSS until the cavity appeared white. After dissociation of red cells with $0.15 \mathrm{M} \mathrm{NH}_{4} \mathrm{Cl}, 10 \mathrm{mM} \mathrm{KHCO}{ }_{3}, 0.1 \mathrm{mM}$ $\mathrm{Na}_{2}$ EDTA, pH 7.2 (lysis buffer), the cell suspension was passed through a $40-\mu \mathrm{m}$ filter. The BM cells were cultured for 7 days in complete medium (CM; Dulbecco's modified Eagle's medium [DMEM] supplemented with $10 \%$ fetal bovine serum (FBS), $2 \mathrm{mM}$ L-glutamine, 1\% penicillin/ streptomycin) with $2 \mu \mathrm{g} / \mathrm{ml} \mathrm{M-CSF}$. Nonadherent cells were removed from flasks at 1,4 , and 7 days by successive DMEM washes.

SPL macrophages were obtained by mechanically dissociating spleens in HBSS and then passing the cells through a wire mesh. After dissociation of red cells with lysis buffer, the cell suspension was passed through a $40-\mu \mathrm{m}$ filter. The cells were cultured for 7 days in CM containing MCSF. Nonadherent cells were removed from the flasks at 1 , 4 , and 7 days.

MG were prepared using previously described techniques (Dobrenis, 1998). Brains were removed and placed in HBSS at $4^{\circ} \mathrm{C}$. The tissue was triturated gently by pipetting through a $10-\mathrm{ml}$ pipette. The cell suspension was then incubated in $0.1 \%$ trypsin at $37^{\circ} \mathrm{C}$ for $30 \mathrm{~min}$. After adding cold heat-inactivated FBS, the tissue was washed several times with cold HBSS and filtered through a $40-\mu \mathrm{m}$ filter. The cells were then cultured for 7 days in CM with M-CSF. To obtain highly purified MG, the culture flasks were shaken gently, and the supernatants containing floating MG were transferred to a new flask. The new flasks were incubated for $30 \mathrm{~min}$ to allow the MG to adhere; loose cells were then removed from the flask by washing with DMEM. The adherent MG was cultured for an additional 7-10 days. MP purity was confirmed by CD11b immunocytochemical and by morphological examination. CD11b was expressed in $>98 \%$ cells, regardless of tissue site. All MP subtypes demonstrated enlarged horseshoe-shaped nuclei, dense granular cytoplasm, microvillus processes, prominent rough-surfaced endoplasmic reticulum, and large numbers of endosomes, lysosomes, mitochondria, and cytoplasmic vacuoles.

\section{Preparation of Cell Lysates for Proteomic Analysis}

Cells were washed three times with phosphate-buffered saline (PBS), aliquoted, and stored at $-80^{\circ} \mathrm{C}$ before use. Lysates were prepared with $5 \mathrm{mM}$ Tris- $\mathrm{HCl}, \mathrm{pH}$ 8.0, protease inhibitor cocktail (Sigma, St Louis, MO), and either 2\% Tri- ton X-100 or 2\% 3-[(3-cholamidopropyl) dimethylammonio]-1-propanesulfonate (CHAPS). Protein was quantified using the BCA Protein Assay (Pierce; Rockford, IL) following the manufacturer's instructions.

The protein signatures of whole cell lysates was performed by SELDI-TOF ProteinChip assays (Ciphergen Biosystems, Fremont, CA). The chip types (WCX2, SAX2, and H50) and the washing conditions (0.1 M ammonium acetate, $\mathrm{pH} 4$-10; $50 \mathrm{mM}$ Tris- $\mathrm{HCl}$, pH 4-10; acetonitrile [ACN], 0-50\%) were optimized before analysis. ProteinChip with weak cationic exchange chemistry (WCX2) was selected to profile each of the three cell lysates. The spot surface of each WCX2 chip was pretreated with 10 $\mathrm{mM} \mathrm{HCl}$ and was equilibrated with wash buffer $(0.1 \mathrm{M}$ ammonium acetate, $\mathrm{pH} 4.0$, with $0.1 \%$ Triton X-100). An aliquot of cell lysate mixture $(0.25 \mu \mathrm{g})$ was applied to each spot and incubated in a bioprocessor at room temperature for $30 \mathrm{~min}$ with shaking. Unbound proteins were removed by washing spots twice with wash buffer and then with HPLC grade water. After drying of the spot, 100\% sinapic acid (SPA) was applied to each spot and air-dried. SPA was prepared as a saturated solution in energy absorbing molecule solvent containing 30\% ACN, 15\% isopropanol, $0.5 \%$ trifluoroacetic acid, and $0.05 \%$ Triton X-100. The ionized proteins and their molecular mass/charge $(\mathrm{m} / \mathrm{z})$ ratios were detected using SELDI-TOF analysis. The SELDITOF mass spectra were collected by a PBS II ProteinChip Biosystems and analyzed with ProteinChip software 3.2 (both from Ciphergen Biosystems). The ProteinChip analyses were performed in triplicate, three separate times and on three independent macrophage cultures; the data set from each MP comprised a minimum of 30 spectra. The ProteinChip Reader was externally calibrated for each analysis using the four standard proteins: bovine insulin $(5,733.6 \mathrm{Da})$, cytochrome C (12,230.9 Da), superoxide dismutase (SOD) $(15,591.4 \mathrm{Da})$, and $\beta$-lactoglobulin (18,363.3 Da). Peaks were automatically detected using the Biomarker Wizard of ProteinChip software 3.2. The following parameters for peak detection were used: firstpass signal/noise $(S / N)$ ratio $=5$, second-pass $S / N$ ratio $=2$, and mass tolerance $=0.5 \%$; estimated peaks were included in completion of clustering.

\section{HPLC}

HPLC protein fractionation was performed using a liquid chromatography system (Shimadzu, Columbia, MD). The HPLC system included pump, system controller, manual injector with a 500- $\mu 1$ injection loop, ultraviolet-visual (UVVis) detector set at $220 \mathrm{~nm}$, and fraction collector (all Shimadzu). The HPLC system was controlled with a Dell computer and EZStart chromatographic software (Shimadzu). The mobile phase consisted of $0.1 \mathrm{M}$ ammonium acetate, $\mathrm{pH} 4.0$, as mobile phase $\mathrm{A}$ and $0.1 \mathrm{M}$ ammonium acetate + $0.5 \mathrm{M} \mathrm{NaCl}$, pH 4.0, as mobile phase B. Chromatographic separations were achieved using a weak cation exchange column $(100 \times 2.1 \mathrm{~mm}$; Eprogen, Darien, IL). The flow rate 
was set at $0.2 \mathrm{ml} / \mathrm{min}$. Before sample injection, the chromatographic column was pretreated with $10 \mathrm{mM} \mathrm{HCl}$ for $20 \mathrm{~min}$ and equilibrated with mobile phase A. After sample injection, mobile phase $\mathrm{A}$ was continued for $30 \mathrm{~min}$ then mobile phase $\mathrm{B}$ continued from $30 \mathrm{~min}$ to $60 \mathrm{~min}$. A total of $400 \mu \mathrm{g}$ of CHAPS-lysed cells were injected onto the column $(200 \mu \mathrm{g}$ at 0 and $12 \mathrm{~min}$ of mobile phase A). Under these chromatographic conditions, bound proteins were eluted at 40-50 $\mathrm{min}$. The eluted fractions were dialyzed using CelluSep ${ }^{\circledR} \mathrm{H} 1$ cellulose membranes (Membrane Filtration Products, Seguin, TX).

\section{In Gel Tryptic Digestion}

HPLC fractions were diluted with NuPAGE® LDS buffer (Invitrogen, Carlsbad, CA) and then separated by electrophoresis. In this study, $20 \mu \mathrm{g}$ of each fraction was applied to each well of a NuPAGE $®$ Novex $10 \%$ Bis-Tris (Invitrogen) gel and, after electrophoresis, stained by brilliant blue G-colloidal concentrate (Sigma). Specific protein bands corresponding to molecular weights of interest were cut out using a clear razor blade. After destaining with $50 \% \mathrm{ACN}, 50 \mathrm{mM} \mathrm{NH}_{4} \mathrm{HCO}_{3} / 50 \% \mathrm{ACN}$, and $10 \mathrm{mM}$ $\mathrm{NH}_{4} \mathrm{HCO}_{3} / 50 \%$, the gel slices were dried then incubated with trypsin (Promega; Madison, WI) for 12-16 h. All peptides extracted by $0.1 \%$ trifluoroacetic acid/ $60 \% \mathrm{ACN}$ were pooled into a glass tube and dried prior to LC-MC/ MS tests.

\section{Protein Identification by LC-MS/MS}

The peptides were resuspended in $0.1 \%$ formic acid in HPLC-grade water and the ionized peptides were detected on a QSTAR LC-MS/MS system (Applied Biosystems, Foster City, CA). The spectra from LC-MS/MS analysis were searched using Mascot search engine from Matrix Science (http://www.matrixscience.com/). All protein identifications were confirmed by three criteria, including (1) detection of more than two peptides, (2) protein score of $>100$, and (3) protein mass of $<17 \mathrm{kDa}$.

\section{Western Blot Assays}

HPLC fractions of three MP were diluted with $\mathrm{Nu}$ PAGE LDS sample buffer, and $5 \mu \mathrm{g}$ of each sample was applied to each well of a NuPAGE Novex $10 \%$ Bis-Tris gel (Invitrogen). The gel was transferred to ImmobilonP PVDF transfer membrane (Millipore, Bedford, MA). After blocking with $3 \%$ milk in TBS, the membrane was incubated with sheep anti-mouse SOD antibodies (Calbiochem, San Diego, CA) followed by incubation with horseradish peroxidase-conjugated anti-sheep IgG (Calbiochem). A chemiluminescent signal was detected using SuperSignal ${ }^{\circledR}$ West Pico Chemiluminescent substrate (Pierce). The density of protein bands was determined using the GelExpert software system (Nucleotech, San Carlos, CA).

\section{Statistical Analysis}

We applied discriminant analysis to the log intensities of peaks whose distributions were found to differ by MP subtype. Data from the Biomarker Wizard ${ }^{\circledR}$ software 3.2 were exported for statistical analysis using SAS ${ }^{\circledR}$ software (SAS Institute, Cary, NC). Kruskal-Wallis nonparametric analysis of variance was used to identify peaks for which there were statistically significant differences in the distribution of intensity scores among the three sample types. Because of the large numbers of comparisons made, only those associated with $P$-values of $<0.0001$ were listed as significant. Following the recommendations of Yasui et al. (2003), we analyzed significant peaks in the mass charge range of $1,500-20,000$ in a stepwise discriminant analysis. We then used canonical tests to define a linear construct of peak locations providing maximum discrimination among the MP subtypes. To estimate accuracy, we employed a "leave one out" approach by computing canonical variables using all but one of the observations. The canonical variables were then used to predict the subtype membership of the observation excluded from the calculations. This process produces a more unbiased estimate of the misclassification rate than that obtained from using the data set in toto.

\section{Results}

\section{Protein Profiling of MP Subtypes}

We used SELDI-TOF ProteinChip assays to identify potential cytosolic proteins of BM and SPL macrophages and MG. SELDI-TOF combines one step fractionation of proteins with mass spectrometry. Figure 1a-e shows five spectra representing protein profiles of cell lysates of SPL macrophages from five independent experiments. Higher variability of several peak intensities (e.g., peak 3,977.4 m/ z), as compared with other peaks (e.g., $8,568.5 \mathrm{~m} / \mathrm{z}$ ), were observed. Nevertheless, the SELDI-TOF spectra, in general, demonstrate reproducible spectral patterns. A total of 91 spectra were prepared from the cell lysates of BM and SPL macrophages and MG after Triton X-100 cell lysis. These were combined in one file and analyzed by the Biomarker Wizard program for peak detection. Out of 58 peaks, Kruskal-Wallis analysis identified 19 proteins for which peak intensities differed significantly among MP subtypes $(P<$ $0.0001)$. Table 1 presents a list of "potential" protein locations and median peaks representing proteins. Four peaks were observed to be higher in MG than in BM, and the other MG peaks had similar or lesser intensity than those for BM. Of four peaks with higher intensities, two peaks of 7510.2 and $14999.3 \mathrm{~m} / \mathrm{z}$ showed similar intensities with SPL, while the other two, 7410.3 and $14803.6 \mathrm{~m} / \mathrm{z}$, showed the highest intensity in all three MP subtypes (Fig. 2b,d). Three peaks of $3775.6,3929.7$, and $11318.4 \mathrm{~m} / \mathrm{z}$ were not detected in MG but were present in BM and SPL lysates (Fig. 2a,c). 


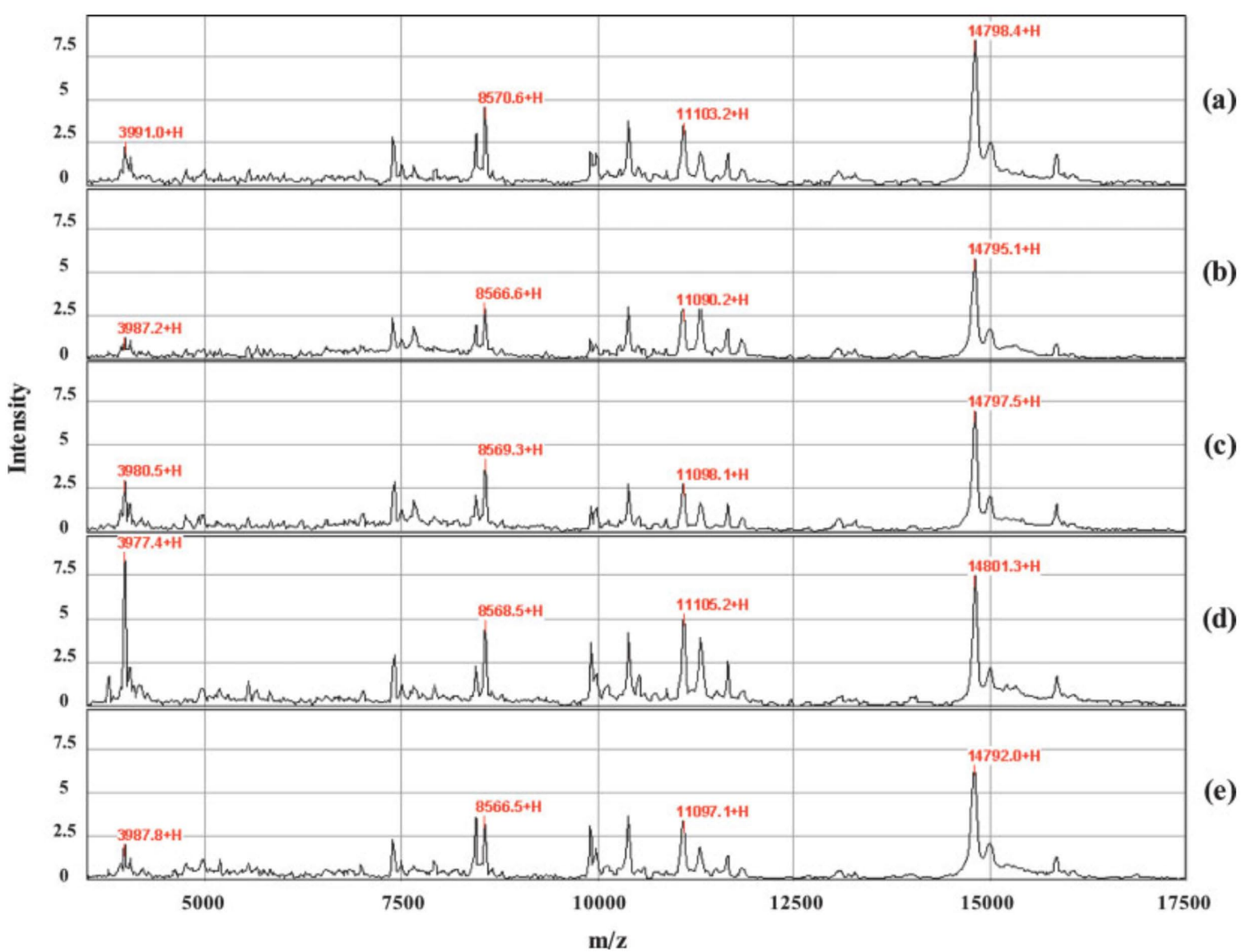

Figure 1. SELDI-TOF ProteinChip ${ }^{\circledR}$ spectra reproducibility tested with SPL macrophage lysates. a,b: represent spectra of identical cell lysate and ProteinChips ${ }^{\circledR}$. c: Spectrum of the same cell lysates as (a) and (b), but using a replicate chip. d,e: represent spectra from distinct cell lysates and chips. Triton X-100 lysis buffer was used to generate the SPL lysates.

Table 1. SELDI-TOF Analysis of MP Subtypes Using Triton X-100 Lysis Buffer*

\begin{tabular}{|c|c|c|c|c|c|c|c|c|}
\hline \multirow[b]{2}{*}{ Peak No. ${ }^{a}$} & \multirow[b]{2}{*}{$\mathrm{m} / \mathrm{z}^{\mathrm{b}}$} & \multicolumn{2}{|c|}{$\mathrm{BM}$} & \multicolumn{2}{|c|}{ SPL } & \multicolumn{2}{|c|}{ MG } & \\
\hline & & Mean & SEM & Mean & SEM & Mean & SEM & \\
\hline 2 & 3775.6 & 0.42 & 0.03 & 0.60 & 0.08 & 0.17 & 0.02 & \\
\hline 4 & 3985.1 & 2.11 & 0.17 & 3.06 & 0.52 & 1.03 & 0.09 & \\
\hline 5 & 4042.6 & 0.77 & 0.04 & 1.23 & 0.09 & 0.58 & 0.04 & $X$ \\
\hline 6 & 4097.2 & 0.41 & 0.03 & 0.55 & 0.06 & 0.23 & 0.02 & \\
\hline 19 & 7410.3 & 1.05 & 0.05 & 1.97 & 0.15 & 2.67 & 0.13 & \\
\hline 20 & 7510.2 & 0.61 & 0.03 & 0.91 & 0.06 & 1.03 & 0.05 & $X$ \\
\hline 23 & 8456.6 & 1.03 & 0.07 & 2.02 & 0.16 & 1.04 & 0.06 & $x$ \\
\hline 27 & 10394.4 & 1.48 & 0.08 & 2.59 & 0.20 & 1.23 & 0.09 & \\
\hline 30 & 11110.0 & 1.37 & 0.15 & 2.92 & 0.30 & 1.05 & 0.10 & $X$ \\
\hline 39 & 14803.6 & 2.47 & 0.11 & 5.13 & 0.35 & 7.05 & 0.37 & $X$ \\
\hline 40 & 14999.3 & 0.87 & 0.04 & 1.63 & 0.09 & 1.89 & 0.08 & \\
\hline 42 & 15857.1 & 0.77 & 0.04 & 1.02 & 0.08 & 0.42 & 0.03 & $X$ \\
\hline
\end{tabular}

${ }^{*}$ Kruskal-Wallis analysis of variance comparing distribution of peak intensities across MP subtypes. $\mathrm{X}=$ Peaks selected as useful for prediction for subset membership.

a A total 58 peaks were detected from data generated from SELDI-TOF ProteinChip ${ }^{\circledR}$ assays and were numbered 1-58.

${ }^{\mathrm{b}}$ Mass/charge $(\mathrm{m} / \mathrm{z})$ is indicated as median mass of corresponding peaks from all spectra. 


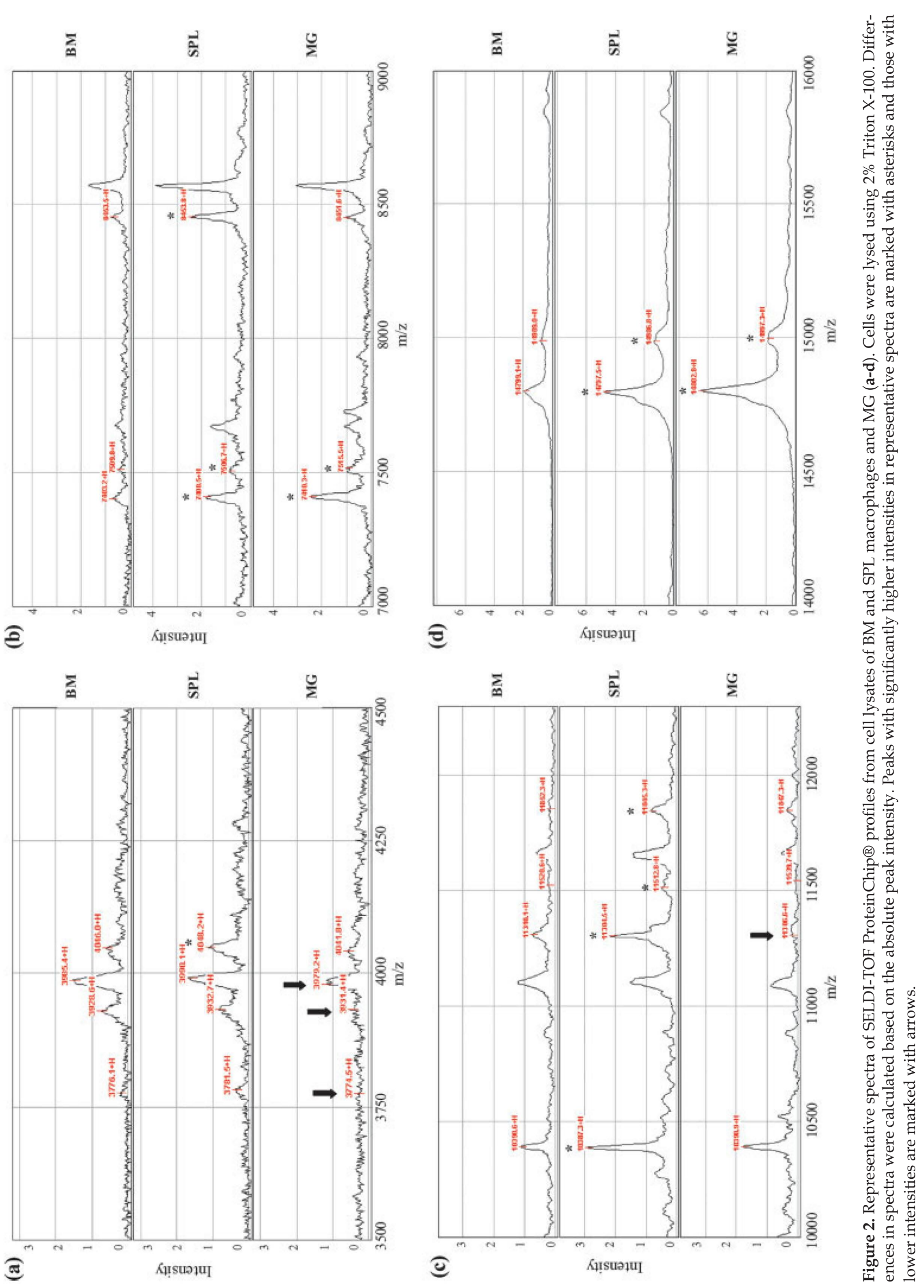


Table 2. SELDI-TOF Analysis of MP Subtypes Using CHAPS Lysis Buffer*

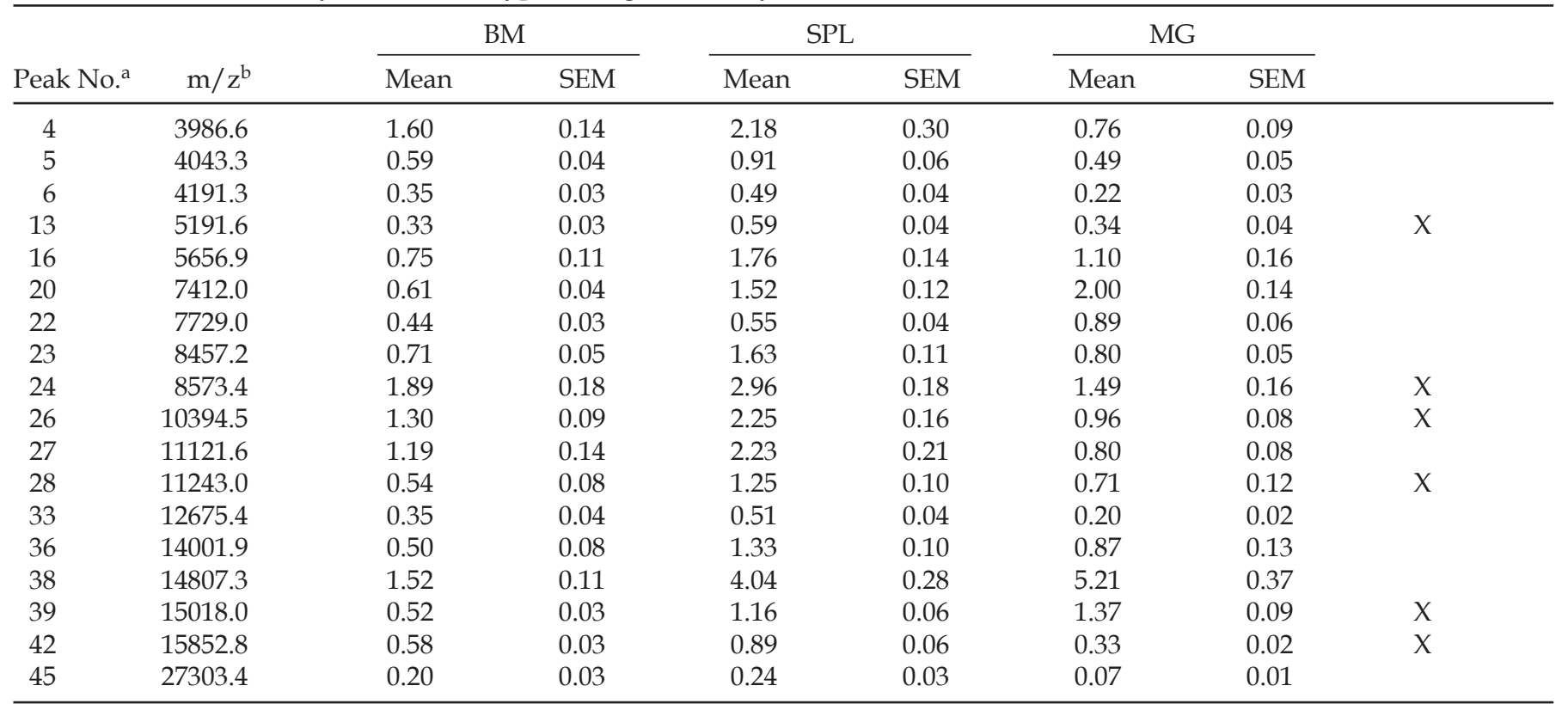

${ }^{*}$ Kruskal-Wallis analysis of variance comparing distribution of peak intensities across MP subtypes. $\mathrm{X}=$ Peaks selected as useful for prediction of subtype membership.

a A total 61 peaks were detected from data generated using SELDI-TOF ProteinChip ${ }^{\circledR}$ assay and were numbered 1-61.

${ }^{\mathrm{b}}$ Mass/charge $(\mathrm{m} / \mathrm{z})$ is indicated as median mass of corresponding peaks from all spectra.

\section{Detergents Affect Protein Profiling}

To examine how detergents affect SELDI-TOF spectra, we lysed cells using $2 \%$ CHAPS and generated 92 spectra from $\mathrm{BM}$ and SPL macrophages and MG in identical manner as those 91 spectra analyzed following 2\% Triton X-100 lysis. In this comparison, all spectra from MP lysates prepared with CHAPS were combined in one file and analyzed using Biomarker Wizard generating a total of 62 peaks. Statistical comparisons based on absolute intensity yielded 18 significantly different peaks among the MP subtypes $(P<$ 0.0001 ). Table 2 presents a summary of peaks, characteristic for BM and SPL macrophages and MG. Protein peaks with both higher and lower intensities were observed for the three MP subtypes (Fig. 3). Spectral comparisons between SPL and BM macrophages showed that all 18 peaks were higher in SPL macrophages. The results from two experiments yielded similar results. In particular, eight peaks of 3986.6, 4043.3, 5656.9, 8457.2, 8573.4, 10394.5, 11121.6, and $15852.8 \mathrm{~m} / \mathrm{z}$ showed highest intensity in SPL relative to other MP subtypes (Fig. 3). The profiles of MG showed four higher and two lower peaks, as compared with BM macrophages. Four peaks of higher 7412.0, 7729.0, 14807.3, and $15018.0 \mathrm{~m} / \mathrm{z}$ were higher in MG than in BM and SPL macrophages (Fig. 3b,c,d). In contrast, two peaks of 3986.6 and $15852.8 \mathrm{~m} / \mathrm{z}$ were detected in BM and SPL macrophages, but not in MG (Fig. 3a,d).

Differences in protein profiles were detected regardless of the lysis buffer used. However, CHAPS and Triton X-100 elicited different protein profiles (Tables 1 and 2). Comparison of the data sets between CHAPS- and TritonX100-lysed cells showed that seven peaks of 3986.6, 4043.3, 7412.0, 8457.2, 10394.5, 14807.3, and $15852.8 \mathrm{~m} / \mathrm{z}$, summa- rized in Table 2, were detected in both lysis conditions. In contrast, seven peaks of 5191.6, 5656.9, 7729.0, 8573.4, $11243.0,12675.4$, and $14001.9 \mathrm{~m} / \mathrm{z}$ were detected only in CHAPS-lysed cells and showed significantly higher intensities in SPL macrophages and/or MG (Fig. 3). In cells lysed with Triton X-100, four proteins of 7510.2, 11318.4, 11511.2, and $11847.4 \mathrm{~m} / \mathrm{z}$ showed higher intensities in SPL macrophages, two peaks of 7510.2 and $11318.4 \mathrm{~m} / \mathrm{z}$ showed higher and lower intensities in MG, respectively. However, no significant changes in these peaks were found in spectra of CHAPS-lysed cells. The results demonstrate that comparisons of spectra between cell groups must take into account how the cell lysates were prepared.

\section{Canonical Analysis of MP Subtypes}

We used the log intensities of peak distributions, differing by subtype (Tables 1 and 2) in a discriminant analysis to assess cell membership. The peak identified at a median of 27,303.4 identified in the analysis of the CHAPS data was eliminated from this analysis, as it fell outside the ranges recommended by Yasui et al. (2003). Thus, 19 and 17 statistically significant peaks were used in the analysis of the Triton X-100 and CHAPS data, respectively. The stepwise discriminant analysis identified seven peaks for the Triton X-100 data and eight peaks in the CHAPS data, which were useful in the classification of samples into subtypes. Using these peaks, we produced canonical variables with the canonical discriminant procedure. The first two canonical variables provided excellent discrimination between the MG and the other two macrophage subtypes (Fig. 4a,b). The separation of the BM and SPL macrophages was more limited. Nevertheless, assigning samples to subtypes, i.e., 


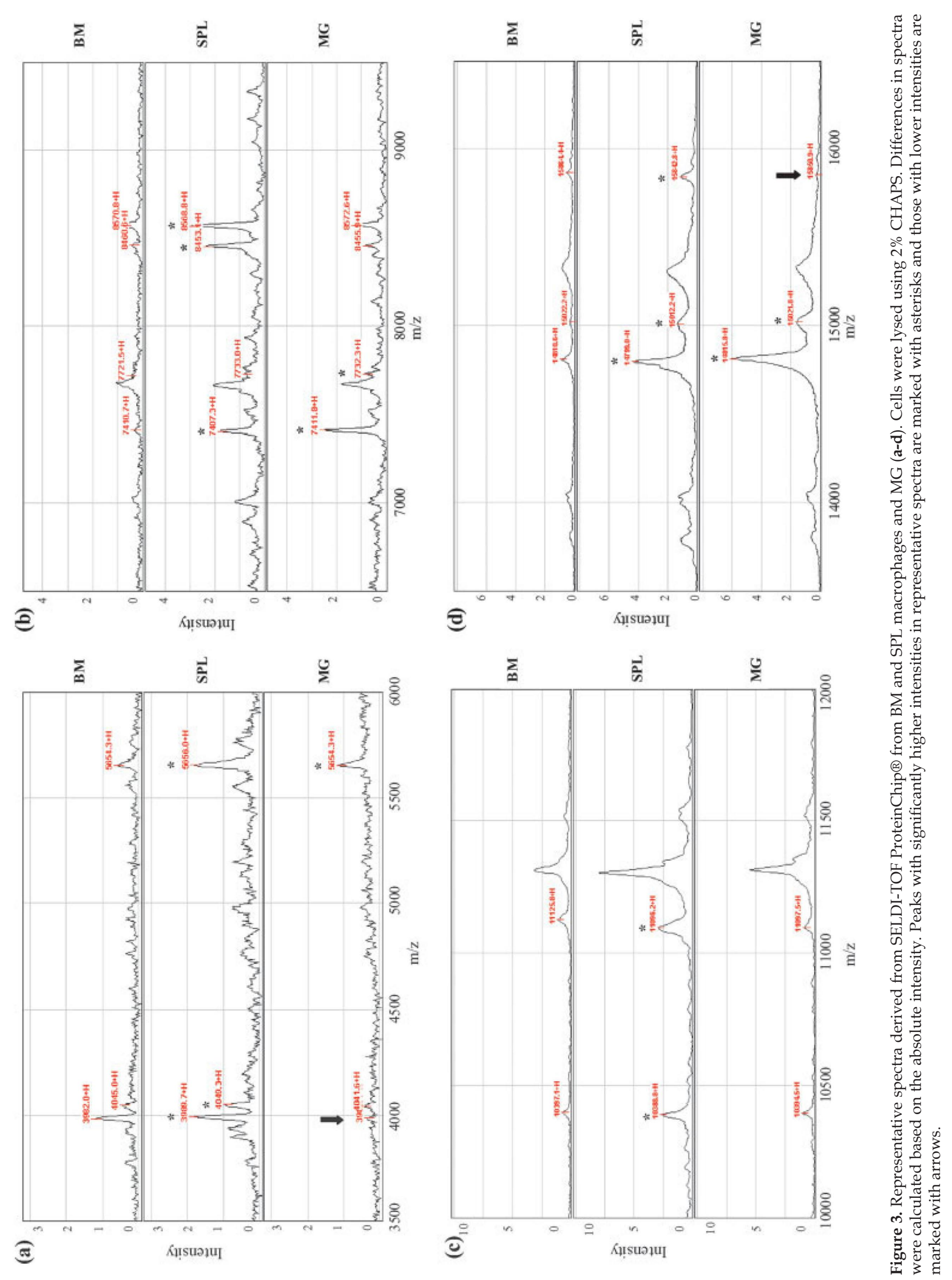


(a)

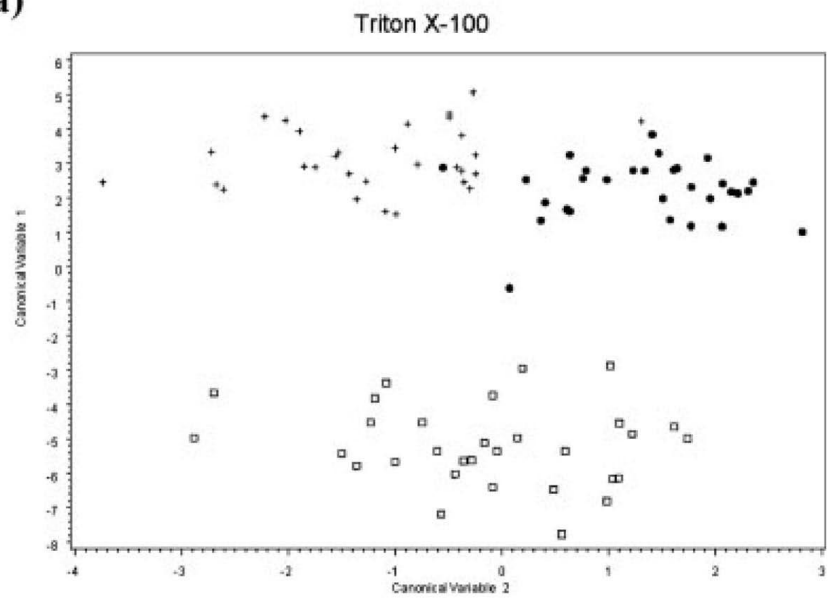

(b)

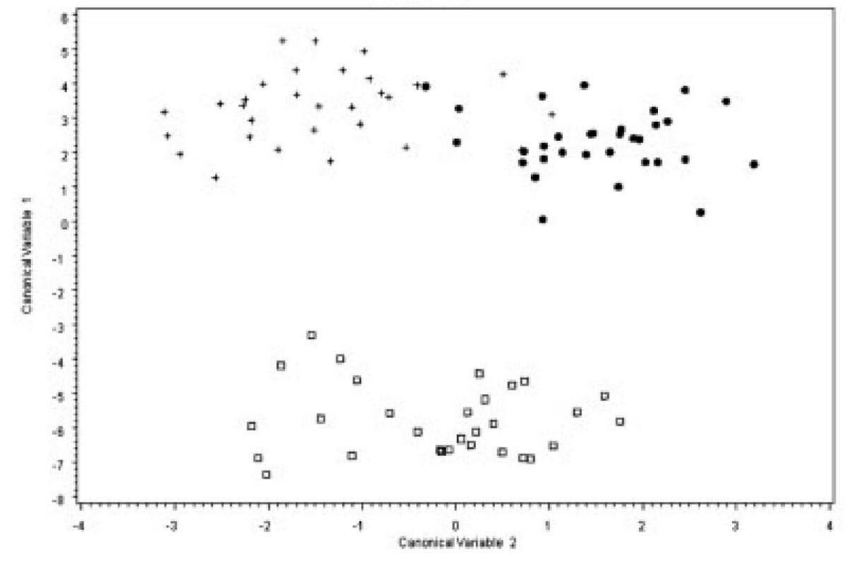

Figure 4. Analysis of 183 SELDI-TOF ProteinChip® spectra demonstrating two-dimensional distribution of canonical variables for BM macrophages (plus), SPL macrophages (closed circle), and MG (opened square). Analyses shown are with Triton X-100 (a) and CHAPS (b) lysis buffers.

MG: canonical variable 1 (CV1) value < 0 ; $\mathrm{BM}$ : CV1 > 0; CV2 < 0; SPL: CV1 > 0; CV2 > 0, led to the misclassification of only three of 91 samples from the Triton X-100 lysates: one BM sample was misclassified as SPL, and two SPL samples were misclassified, one as BM and one as MG. The "leave one out" estimate of the misclassification rate was also 3/91 (3\%). Analysis of the CHAPS lysates led to the misclassification of four of 92 samples (one SPL as BM, three BM as SPL), with the "leave one out" estimate of the misclassification rate being $7 / 92(8 \%)$.

\section{Protein Identification by LC-MS/MS}

To identify the unique proteins determined by SELDITOF analysis, pre-fractionation was required. Here, the design linked SELDI-TOF and HPLC. The techniques used a WCX2 ProteinChip (SELDI-TOF) and WCX column (HPLC). A representative chromatogram is shown in Figure 5a. After sample injections, two peaks were detected at
$4.5 \mathrm{~min}$ and at $16.5 \mathrm{~min}$ during washing and one peak was detected at 42.5 min during elution. The chromatographic pattern was reproducible among all three MP subtypes (data not shown). We collected the fractions that contained the peak detected at $42.5 \mathrm{~min}$ during elution. To examine whether the HPLC fractions showed spectra that corresponded to the SELDI-TOF, we performed ProteinChip assays from the HPLC fractions of three MP subtypes using a WCX2 chip. Sixty peaks were detected from the spectra performed from the HPLC fractions of three MP subtypes (Fig. 5b). Spectral differences among the whole cell lysates and HPLC fractions might be due to differences between protein binding affinities of the WCX2 chip and column. These results revealed that spectral profiling obtained following HPLC fractionation corresponded to SELDI-TOF analysis.

We then separated the proteins enriched by HPLC on 1D SDS-PAGE and the protein bands at $\sim 17 \mathrm{kDa}$ were collected (Fig. 5c). After in-gel tryptic digestion of the bands, the resultant peptides were analyzed by LC-MS/MS; database searching revealed 16 proteins obtained after WCX protein binding and present in the three MP subtypes (Table 3). Five proteins, lysozyme M precursor, AK007994 NID, lipid-binding protein, thioredoxin, and ubiquitin, were detected in all three MP subtypes. However, some proteins were detected only in one or two of MP subtypes. Next, we compared the protein mass identified by LC-MS/MS with those of whole cell lysates or HPLC fractions detected by SELDI-TOF (Table 3). Five proteins, SOD, lipid-binding protein, D-dopachrome tautomerase, AK002403 NID, and ubiquitin, were matched less than $1.0 \%$ mass accuracy of proteins detected in HPLC fractions between SELDI-TOF and LC-MS/MS. Three proteins, SOD, lipid-binding protein, and ubiquitin, were detected both in whole cell lysates and HPLC fractions of the MP subtypes. Two proteins, including lipid-binding protein and ubiquitin, were identified in all three MP subtypes, and showed spectral peaks of 15018.0 and $8573.4 \mathrm{~m} / \mathrm{z}$ by SELDI-TOF. SOD was matched at $0.3 \%$ and $0.2 \%$ mass accuracy by SELDI-TOF spectra of whole cell lysates and by analysis of HPLC fractions. Interestingly, SOD was not detected in HPLC fractions of MG by LC-MS/MS, as the protein peaks with $15852.8 \mathrm{~m} / \mathrm{z}$ was lower in MG whole cell lysates than in BM and SPL whole cell lysates (Tables 2 and 3). To confirm the protein expressions of SOD in all MP subtypes, Western blot was performed in HPLC fractions of the three MP subtypes. Three independent experiments demonstrated that the expression of SOD was lowest in MG when compared with BM and SPL macrophages (Fig. 6). These results supported the data from SELDI-TOF, which MG had a low intensity of peak $15852.8 \mathrm{~m} / \mathrm{z}$ on WCX2 chip, and demonstrated the identification of $15852.8 \mathrm{~m} / \mathrm{z}$ protein peak as SOD.

\section{Discussion}

Although residential tissue macrophage, such as Kupffer cells, alveolar macrophages, and MG, originate from common bone marrow progenitors, they display tissue hetero- 
(a)
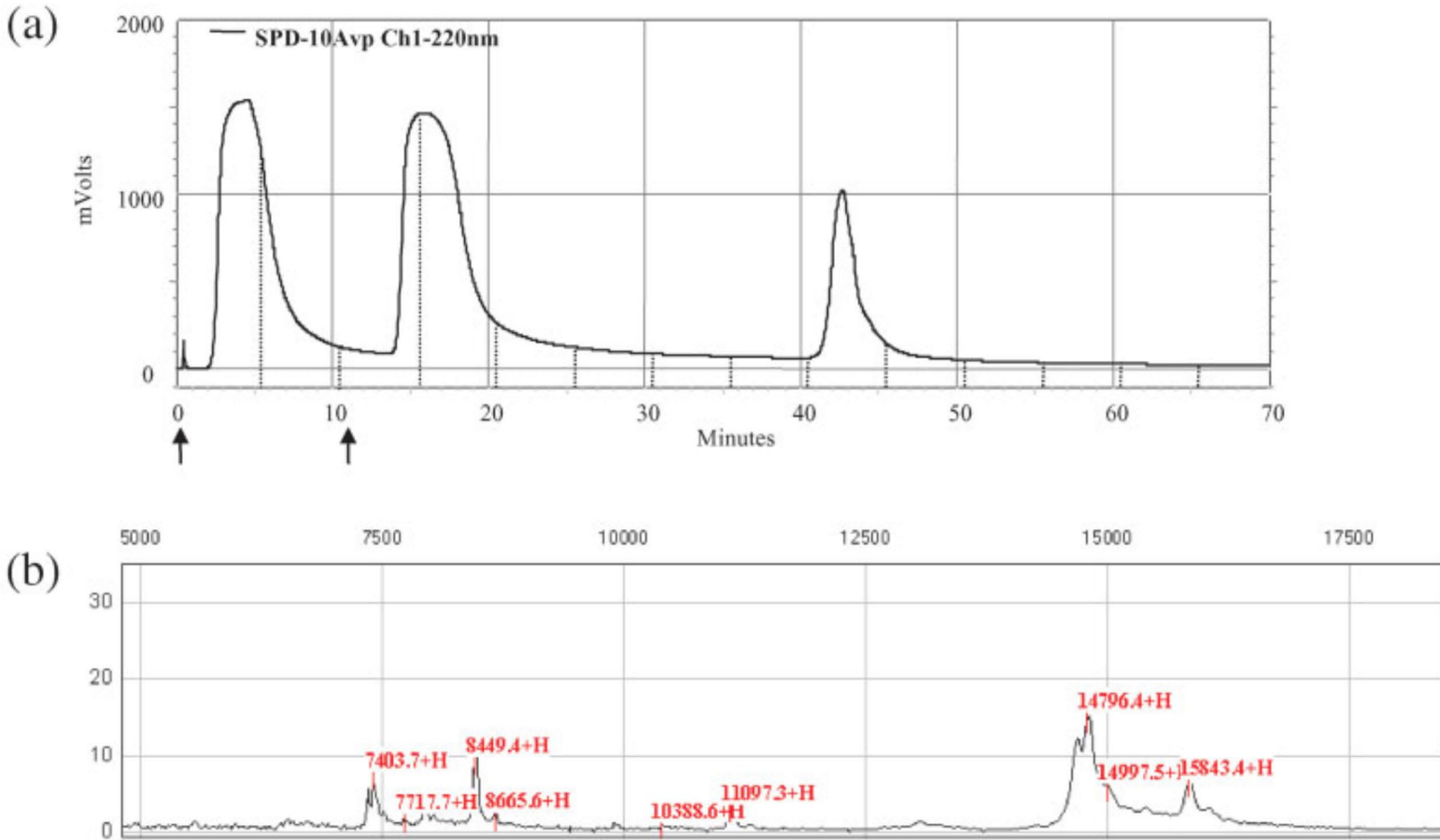

BM

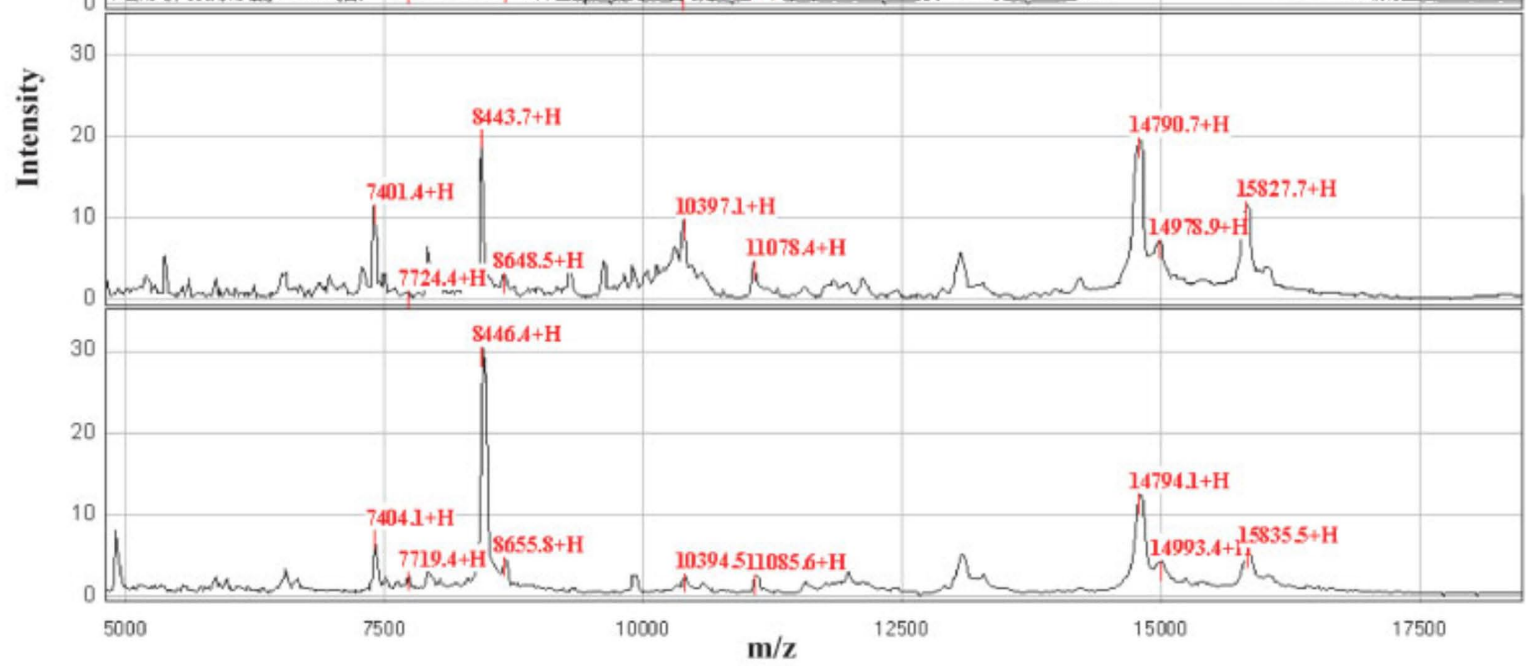

SPL

MG

(c)

BM

SPL

MG

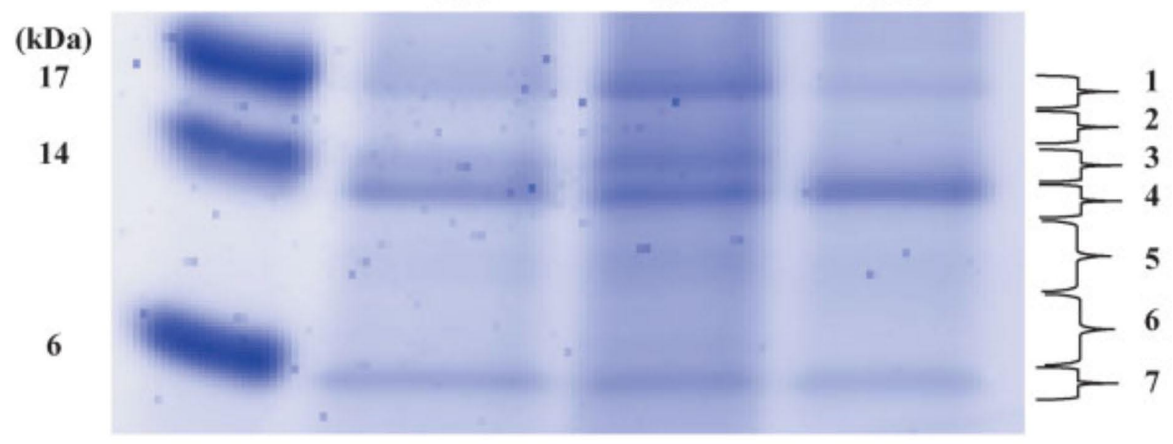

Figure 5. Fractionation of BM and SPL macrophages and MG cell lysates by HPLC. a: Chromatograph of HPLC fractionation of MP cell lysates injected twice into a WCX column at time points marked with arrows. b: SELDI-TOF ProteinChip ${ }^{\circledR}$ spectra were derived from HPLC fractions from BM and SPL macrophages and MG. Spectral peaks marked with red indicate the identical peaks of "putative" proteins shown in Table 2. c: One dimensional (1D) gel of HPLC fractions of BM and SPL macrophages and MG. Protein bands 1-7 were cut then collected for protein identification using LC-MS/MS. 
Table 3. Protein Identification for MP Subtypes*

\begin{tabular}{|c|c|c|c|c|c|c|c|}
\hline \multirow[b]{2}{*}{ Accession no. } & \multirow[b]{2}{*}{ Protein name } & \multirow[b]{2}{*}{ Mass } & \multicolumn{3}{|c|}{ Sequence coverage (\%) } & \multicolumn{2}{|c|}{ SELDI-TOF ${ }^{\mathrm{a}}$} \\
\hline & & & $\mathrm{BM}$ & SPL & MG & $\begin{array}{l}\text { Whole cell } \\
\text { lysate }\end{array}$ & $\begin{array}{l}\text { HPLC } \\
\text { fraction }\end{array}$ \\
\hline GLMB_MOUSE & $\begin{array}{l}\text { Glia maturation factor beta (GMF } \beta \text { ): } \\
\text { Mus musculus (mouse) }\end{array}$ & 16581 & ND & 7 & ND & & \\
\hline BAB25396 & AK007994 NID: Mus musculus & 15934 & 41 & 39 & 16 & & \\
\hline Q9R1A1 & $\begin{array}{l}\text { Sodium-hydrogen exchanger regulatory } \\
\text { factor (fragment): Mus musculus (mouse) }\end{array}$ & 15367 & 22 & 22 & ND & & \\
\hline A47497 & Lipid-binding protein, kcratinocyte: mouse & 15127 & 14 & 23 & 22 & $15018.0(0.7)$ & $14979.0(1.0)$ \\
\hline DOPD_MOUSE & $\begin{array}{l}\text { D-dopachrome tautomerase (EC 5.3.3.-): } \\
\text { Mus musculus (mouse) }\end{array}$ & 12938 & ND & 37 & ND & & $13062.4(1.0)$ \\
\hline CCMS & Cytochrome c [validated]: mouse & 11598 & ND & 38 & 26 & & \\
\hline THIO_MOUSE & $\begin{array}{l}\text { Thioredoxin (ATL-derived factor) } \\
\text { (ADF): Mus musculus (mouse) }\end{array}$ & 11537 & 36 & 38 & 21 & & \\
\hline Q7TQ15 & $\begin{array}{l}\text { Dosage compensation-related protein } \\
\text { DPY30: Mus musculus (mouse) }\end{array}$ & 11176 & 36 & 36 & ND & $11121.6(0.5)$ & \\
\hline BAB22074 & AK002403 NID: Mus musculus & 11039 & 29 & ND & ND & & $11082.1(0.4)$ \\
\hline Q9J195 & CPN10-like protein: Mus musculus (mouse) & 10971 & ND & 23 & ND & & \\
\hline JC4760 & SMT3 protein: human & 10864 & 23 & 23 & ND & & \\
\hline UQBO & Ubiquitin: bovine (tentative sequence) & 8560 & 80 & 64 & 64 & $8573.4(0.2)$ & $8650.7(1.0)$ \\
\hline
\end{tabular}

* Protein identification was performed by LC-MS/MS using HPLC fractions of three MP cell lysates.

a Average of protein mass in whole cell lysates and HPLC fractions are shown. Protein mass accuracy between SELDI-TOF and database is indicated as percentage in parentheses.

MP, mononuclear phagocytes; BM, bone marrow; SPL, spleen; MG, (brain) microglia; ND, not detected.

geneity. Differences among macrophage subtypes likely result from combinations of programmed cellular differentiation, tissue distribution, and responsiveness to endogenous and exogenous stimuli (Gordon et al., 1988; Ogawa 1993; Valledor et al., 1998). Thus, if genetically identical, when the cells are removed from their normal environment and cultivated under identical conditions, they would show morphological and functional similarities. We demonstrated that the proteomes of MG, SPL, and BM macrophages could be distinguished one compared to the other. Indeed, MP show unique proteomic profiles even when cultured under identical conditions. These results serve to extend prior MP phenotypic heterogeneity studies, including M-CSF dependency (Cecchini et al., 1994; Naito et al., 1996; de Villier et al., 1998).

ProteinChip technology is a new technology used to study proteomic profiles in biological samples, such as serum, cerebrospinal fluid, and cell or tissue extracts (Merchant and Weinberger, 2000; Wulfkuhle et al., 2001; Carrette et al., 2003; Luo et al., 2003; Carlson et al., 2004), and is used in biomarker discovery (Ball et al., 2002; Choe et al., 2002; Yasui et al., 2002; Hayman and Przyborski, 2004). We used SELDI-TOF to identify protein patterns in BM and SPL macrophages and MG, and showed statistical differences among three MP subtypes. Protein profiling also demonstrated that SPL macrophages showed peak patterns similar to BM macrophages using both lysis extraction methods. The results were supported by canonical analysis. While profiles of SPL macrophages showed similar or higher intensity than BM spectra, profiles of MG showed similar or lower intensities when compared with BM macrophages. Characterization of MG is commonly performed by cytofluorometry and immunohistochemistry (Giulian and Baker, 1986; Ulvestad et al., 1994; Giulian et al., 1995; Becher and Antel, 1996). The phenotype of MG in the normal CNS is described as being in an inactive state (Perry and Gordon, 1991; Sedgwick et al., 1991). However, because activation of MG promotes immune responses, the balance of protective and destructive action is directly related to environmental cues acquired during neurodegenerative disorders (Allan and Rothwell, 2001; Nguyen, 2002). The MG proteome operative during neurodegenerative disorders may be studied if the cells "unique" properties can be maintained during cultivation. Trying to tease out unique signatures of MG is fraught with other difficulties. Indeed, it is likely that MG originate from BM progen- 

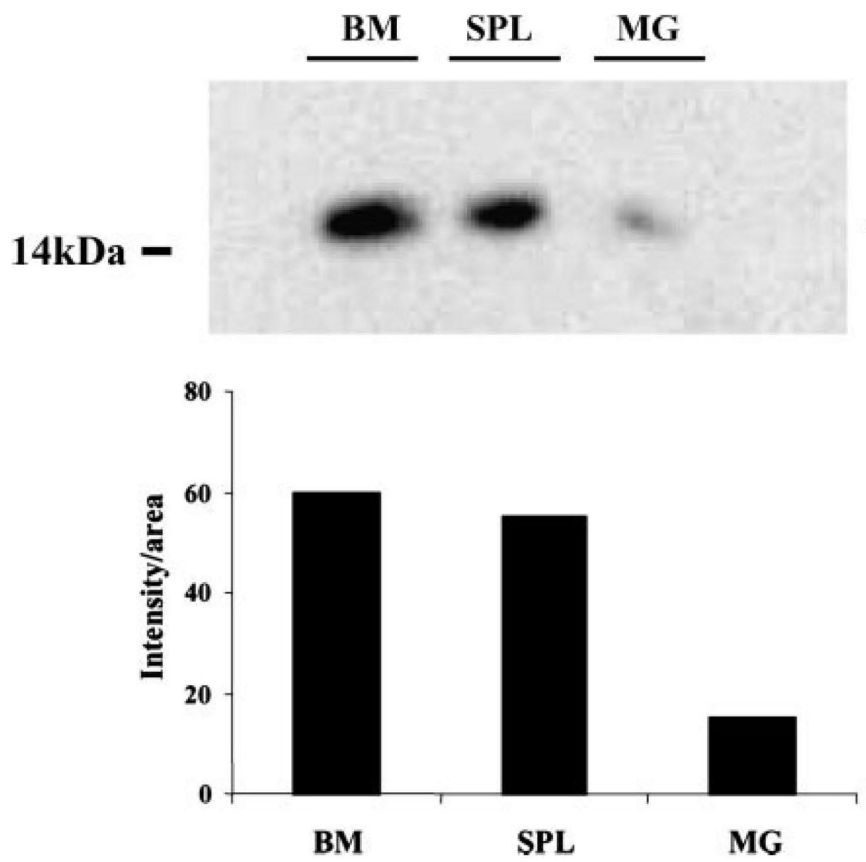

itors and migrate to brain during fetal development. The same BM progenitors also give rise to spleen and other tissue macrophages. Moreover, embryonic and adult mouse brain may themselves contain progenitor cells (Alliot et al., 1991; Richardson et al., 1993). MG may also turn over at a significantly slower rate than other tissue macrophage (Kennedy and Abkowitz, 1997). Thus, distinctive features of MG may be principal in development, differentiation, and plasticity.

While protein analysis have been established as new tools for understanding various biological problems, different mass spectrometric techniques for identification and posttranslational modifications have been established as well as isolation and separation methods for analysis of highly complex samples by classical separation techniques, such as two-dimensional gel electrophoresis and liquid chromatography (Lescuyer et al., 2004; Reinders et al., 2004). Recently, these techniques have been helpful for macrophage proteome analysis (Walsh et al., 1995; Yeung and Stanley, 2003; Yu et al., 2003; Verhoeckx et al., 2004; Dupont et al., 2004). In the present study, we used HPLC as a protein separation method and LC-MS/MS as an identification tool. These analyses showed that of 16 possible proteins three were identified as SOD, lipid-binding protein, and ubiquitin. These corresponded to the spectral peaks detected by SELDI-TOF. The protein peak detected at 15852.8 $\mathrm{m} / \mathrm{z}$ in MG cell lysates showed lower intensities than those in BM and SPL macrophages on the WCX2 chip. This protein peak was identified as SOD in the HPLC fraction of all MP subtypes but showed the lowest level of expression in MG. The results, most significantly, showed that SELDITOF and HPLC can be linked through the use of a WCX chip and column.

Interestingly, the lowest levels of SOD were found in MG. SOD regulates cellular oxygen metabolism and free radical formation. Oxygen free radicals are linked to the
Figure 6. Immunoblot detection of SOD in HPLC fractions of BM and SPL macrophages and MG. Western blot analysis of protein bands of SOD $(15,802$ Da) marked with an arrow. A representative illustration of one of three independent experiments is shown. The relative densities of protein bands for the immunoblot shown is included. pathogenesis of a number of neurodegenerative disorders, including amyotrophic lateral sclerosis and human immunodeficiency virus (HIV) dementia, and are associated with inflammatory responses (Pasinelli et al., 1998; Boven et al., 1999; Marikovsky et al., 2003; Nguyen et al., 2004). Macrophages secrete SOD de novo, but it is increased following cell activation by lipopolysaccharide and tumor necrosis factor- $\alpha$ (TNF- $\alpha$ ) (Marikovsky et al., 2003). In our study, the protein levels in HPLC fraction were different between MG and the other MP subtypes. The difference of quantitative expression might result from the difference of the binding affinity of SOD obtained from each MP against WCX surface. Although it remains unknown whether SOD qualitatively or functionally differ among the three MP, these results might lead to new insights into their roles in health and disease.

Macrophages play a role in tissue homeostasis as specialized phagocytic cells able to produce trophic, cytotoxic, and regulatory molecules that mediate inflammation and repair, following pathogen invasion and cellular damage (Gordon, 2003). The immunological changes in residential cells have influences on tissue structure and function during disease progressions. Therefore, it is important to further characterize the protein expression profiles in resting and activated macrophages, as a first step towards understanding how proteins affect a unique MP subtype.

\section{Acknowledgments}

The authors thank Ms. Robin Taylor for outstanding administrative and graphic support. We thank Dr. Ron Cerny for assistance with the LC-MS/MS protein microsequencing. This work was supported by P01 NS4 National Institutes of Health grants 2R37 NS36126, P01 NS31492, P01 NS43985, U54 NS43011-01, and 2 R01 NS034239 (to H.E.G.) and P20 RR15635 (to P.C. and H.E.G.). 


\section{References}

Allan SM, Rothwell NJ. 2001. Cytokines and acute neurodegeneration. Nat Rev Neurosci 2: 734-744.

Alliot F, Lecain E, Grima B, Pessac B. 1991. Microglial progenitors with a high proliferative potential in the embryonic and adult mouse brain. Proc Natl Acad Sci USA 88: 1541-1545.

Ball G, Mian S, Holding F, Allibone RO, Lowe J, Ali S, Li G, McCardle S, Ellis IO, Creaser C, Rees RC. 2002. An integrated approach utilizing artificial neural networks and SELDI mass spectrometry for the classification of human tumours and rapid identification of potential biomarkers. Bioinformatics 18: 395-404

Becher B, Antel JP. 1996. Comparison of phenotypic and functional properties of immediately ex vivo and cultured human adult microglia. Glia 18: $1-10$.

Boven LA, Gomes L, Hery C, Gray F, Verhoef J, Portegies P, Tardieu M, Nottet HS. 1999. Increased peroxynitrite activity in AIDS dementia complex: implications for the neuropathogenesis of HIV-1 infection. J Immunol 162: 4319-4327.

Carlson KA, Ciborowski P, Schellpeper CN, Biskup TM, Shen RF, Luo X, Destache CJ, Gendelman HE. 2004. Proteomic fingerprinting of HIV-1infected human monocyte-derived macrophages: a preliminary report. J Neuroimmunol 147: 35-42.

Carrette O, Demalte I, Scherl A, Yalkinoglu O, Corthals G, Burkhard P, Hochstrasser DF, Sanchez JC. 2003. A panel of cerebrospinal fluid potential biomarkers for the diagnosis of Alzheimer's disease. Proteomics 3: 1486-1494.

Cecchini MG, Dominguez MG, Mocci S, Wetterwald A, Felix R, Fleisch H, Chisholm O, Hofstetter W, Pollard JW, Stanley ER. 1994. Role of colony stimulating factor- 1 in the establishment and regulation of tissue macrophages during postnatal development of the mouse. Development 120: 1357-1372.

Choe LH, Dutt MJ, Relkin N, Lee KH. 2002. Studies of potential cerebrospinal fluid molecular markers for Alzheimer's disease. Electrophoresis 23: 2247-2251.

de Villiers WJ, Fraser IP, Hughes DA, Doyle AG, Gordon S. 1994. Macrophage-colony-stimulating factor selectively enhances macrophage scavenger receptor expression and function. J Exp Med 180: 705-709.

de Villiers WJ, Smith JD, Miyata M, Dansky HM, Darley E, Gordon S. 1998. Macrophage phenotype in mice deficient in both macrophage-colonystimulating factor (op) and apolipoprotein E. Arterioscler Thromb Vasc Biol 18: 631-640.

Dobrenis K. 1998. Microglia in cell culture and in transplantation therapy for central nervous system disease. Methods 16: 320-344.

Dupont A, Tokarski C, Dekeyzer O, Guihot AL, Amouyel P, Rolando C, Pinet F. 2004. Two-dimensional maps and databases of the human macrophage proteome and secretome. Proteomics 4: 1761-1778.

Giulian D, Baker TJ. 1986. Characterization of ameboid microglia isolated from developing mammalian brain. J Neurosci 6: 2163-2178.

Giulian D, Li J, Bartel S, Broker J, Li X, Kirkpatrick JB. 1995. Cell surface morphology identifies microglia as a distinct class of mononuclear phagocyte. J Neurosci 15: 7712-7726.

Gordon S. 2003. Alternative activation of macrophages. Nat Rev Immunol 3: 23-35.

Gordon S, Keshav S, Chung LP. 1988. Mononuclear phagocytes: tissue distribution and functional heterogeneity. Curr Opin Immunol 1: 26-35.

Guillemin GJ, Brew BJ. 2004. Microglia, macrophages, perivascular macrophages, and pericytes: a review of function and identification. J Leukoc Biol 75: 388-397.

Hamilton JA. 1997. CSF-1 signal transduction. J Leukoc Biol 62: 145-155.

Hayman MW, Przyborski SA. 2004. Proteomic identification of biomarkers expressed by human pluripotent stem cells. Biochem Biophys Res Commun 316: 918-923.

Kaplan G, Walsh G, Guido LS, Meyn P, Burkhardt RA, Abalos RM, Barker J, Frindt PA, Fajardo TT, Celona R, Cohn ZA. 1992. Novel responses of human skin to intradermal recombinant granulocyte/macrophagecolony-stimulating factor: Langerhans cell recruitment, keratinocyte growth, and enhanced wound healing. J Exp Med 175: 1717-1728.

Kennedy DW, Abkowitz JL. 1997. Kinetics of central nervous system microglial and macrophage engraftment: analysis using a transgenic bone marrow transplantation model. Blood 90: 986-993.

Laskin DL, Weinberger B, Laskin JD. 2001. Functional heterogeneity in liver and lung macrophages. J Leukoc Biol 70: 163-170.

Lescuyer P, Hochstrasser DF, Sanchez JC. 2004. Comprehensive proteome analysis by chromatographic protein prefractionation. Electrophoresis 25: 1125-1135.
Luo X, Carlson KA, Wojna V, Mayo R, Biskup TM, Stoner J, Anderson J, Gendelman HE, Melendez LM. 2003. Macrophage proteomic fingerprinting predicts HIV-1-associated cognitive impairment. Neurology 60: 1931-1937.

Marikovsky M, Ziv V, Nevo N, Harris-Cerruti C, Mahler O. 2003. Cu/Zn superoxide dismutase plays important role in immune response. J Immunol 170: 2993-3001.

Merchant M, Weinberger SR. 2000. Recent advancements in surface-enhanced laser desorption/ionization-time of flight-mass spectrometry. Electrophoresis 21: 1164-1177.

Morris L, Graham CF, Gordon S. 1991. Macrophages in haemopoietic and other tissues of the developing mouse detected by the monoclonal antibody F4/80. Development 112: 517-526.

Naito M, Umeda S, Yamamoto T, Moriyama H, Umezu H, Hasegawa G, Usuda H, Shultz LD, Takahashi K. 1996. Development, differentiation, and phenotypic heterogeneity of murine tissue macrophages. I Leukoc Biol 59: 133-138.

Nguyen MD, Julien JP, Rivest S. 2002. Innate immunity: the missing link in neuroprotection and neurodegeneration? Nat Rev Neurosci 3: 216-227.

Nguyen MD, D'Aigle T, Gowing G, Julien JP, Rivest S. 2004. Exacerbation of motor neuron disease by chronic stimulation of innate immunity in a mouse model of amyotrophic lateral sclerosis. J Neurosci 24: 1340-1349.

Ogawa M. 1993. Differentiation and proliferation of hematopoietic stem cells. Blood 81: 2844-2853.

Pasinelli P, Borchelt DR, Houseweart MK, Cleveland DW, Brown RH Jr. 1998. Caspase-1 is activated in neural cells and tissue with amyotrophic lateral sclerosis-associated mutations in copper-zinc superoxide dismutase. Proc Natl Acad Sci USA 95: 15763-15768.

Perry VH, Gordon S. 1991. Macrophages and the nervous system. Int Rev Cytol 125: 203-244.

Reinders J, Lewandrowski U, Moebius J, Wagner Y, Sickmann A. 2004 Challenges in mass spectrometry-based proteomics. Proteomics 4 3686-3703.

Richardson A, Hao C, Fedoroff S. 1993. Microglia progenitor cells: a subpopulation in cultures of mouse neopallial astroglia. Glia 7: 25-33.

Sedgwick JD, Schwender S, Imrich H, Dorries R, Butcher GW, ter Meulen V. 1991. Isolation and direct characterization of resident microglial cells from the normal and inflamed central nervous system. Proc Natl Acad Sci USA 88: 7438-7442.

Taylor PR, Brown GD, Geldhof AB, Martinez-Pomares L, Gordon S. 2003. Pattern recognition receptors and differentiation antigens define murine myeloid cell heterogeneity ex vivo. Eur J Immunol 33: 2090-2097.

Ulvestad E, Williams K, Mork S, Antel J, Nyland H. 1994. Phenotypic differences between human monocytes/macrophages and microglial cells studied in situ and in vitro. J Neuropathol Exp Neurol 53: 492-501.

Valledor AF, Borras FE, Cullell-Young M, Celada A. 1998. Transcription factors that regulate monocyte/macrophage differentiation. J Leukoc Biol 63: 405-417.

van Furth R. 1992. Production and migration of monocytes and kinetics of macrophages. Dordrecht: Kluwer Academic.

van Furth R, Blusse van Oud Alblas A. 1982. The current view on the origin of pulmonary macrophages. Pathol Res Pract 175: 38-49.

Verhoeckx KC, Bijlsma S, de Groene EM, Witkamp RF, van der Greef J, Rodenburg RJ. 2004. A combination of proteomics, principal component analysis and transcriptomics is a powerful tool for the identification of biomarkers for macrophage maturation in the U937 cell line. Proteomics 4: 1014-1028.

Walsh BJ, Gooley AA, Williams KL, Breit SN. 1995. Identification of macrophage activation associated proteins by two-dimensional gel electrophoresis and microsequencing. J Leukoc Biol 57: 507-512.

Wulfkuhle JD, McLean KC, Paweletz CP, Sgroi DC, Trock BJ, Steeg PS, Petricoin EF III. 2001. New approaches to proteomic analysis of breast cancer. Proteomics 1: 1205-1215.

Yasui Y, Pepe M, Thompson ML, Adam BL, Wright GL Jr, Qu Y, Potter JD, Winget M, Thornquist M, Feng Z. 2003. A data-analytic strategy for protein biomarker discovery: profiling of high-dimensional proteomic data for cancer detection. Biostatistics 4: 449-463.

Yeung YG, Stanley ER. 2003. Proteomic approaches to the analysis of early events in colony-stimulating factor-1 signal transduction. Mol Cell Proteomics 2: 1143-1155.

Yu YL, Huang ZY, Yang PY, Rui YC. 2003. Proteomic studies of macrophage-derived foam cell from human U937 cell line using two-dimensional gel electrophoresis and tandem mass spectrometry. J Cardiovasc Pharmacol 42: 782-789. 